\title{
Constructing worlds of education: A historical perspective
}

\author{
Joëlle Droux $\cdot$ Rita Hofstetter
}

Published online: 14 February 2015

(C) UNESCO IBE 2015

\begin{abstract}
Over the past two decades, historians have dedicated a growing amount of research to the history of globalization. This introduction shows how the articles in this issue contribute to this dynamic, aiming to illustrate its heuristic potential in historicizing educational phenomena. The field of education is presented as a relevant platform for an analysis of transnational dynamics, a fact which is demonstrated in the various articles in this issue: they offer a diversity of original case studies that shed new light on the complexity of transfer mechanisms related to education policies, models, and knowledge over the last two centuries. The introduction underlines how this issue renews knowledge on the international production of education policies and practices, focusing on four key methodological issues that run through the various articles: periodization, the myth of progressivism, the multilaterality of circulatory phenomena, and gender relations.
\end{abstract}

Keywords Internationalization - Circulation - Transfers · History of globalization · Education

Over the past two decades, researchers have taken renewed interest in the ways that models, knowledge, policies, and actors have been disseminated, interconnected and transferred, especially as the so-called phenomena of globalization have echoed within

This special issue of Prospects is the result of a collective project on the long-term history of internationalization phenomena, by the research team in the social history of education of the Faculty of Psychology and Educational Sciences at the University of Geneva. A collected volume, in French, due to appear in 2015, will include longer articles from many of the authors in this issue.

J. Droux $(\bowtie) \cdot R$. Hofstetter

University of Geneva, 40 boulevard du Pont d'Arve, 1211 Geneva 4, Switzerland

e-mail: Joelle.Droux@unige.ch

R. Hofstetter

e-mail: Rita.Hofstetter@unige.ch 
various intellectual communities (Clavin 2011; Haupt 2011). Ever attentive to the historical background and context of current processes, historians have also addressed this issue, enrolling themselves in various schools or avenues of research such as histoire croisée (entangled history), along with transnational, global, world, connected or, more recently, shared history. These scholarly efforts have given rise to fascinating debates concerning ideas, productive controversies, and useful refinements of definitions (Clavin 2005; Iriye and Saunier 2009; Macdonald 2013; Tyrrel 2009). True, these various schools and research perspectives certainly advocate diverse and sometimes contradictory approaches. Nevertheless, they meet on the fundamental issue of "envisaging the global approach as a means of studying subjects" (Minard 2013, p. 25), focusing on analyzing phenomena of interconnection (within, beyond, and across borders) through what are sometimes called "relational approaches", which may also cut across fields, subjects, and levels (Werner and Zimmerman 2003). Scholars who are inspired by these approaches are also encouraged to go beyond the "methodological nationalism" imposed by the framework of contemporary states or nations (particularly during the most recent historical periods, which have seen the triumph of the political construct of the nation state) and to embrace "issues and phenomena that are of relevance to the whole of humanity, not just to a small number of countries or to one region of the world" (Iriye 2013, p. 11). Over recent years, this multifaceted tropism, which explains the focus on connection phenomena that are potentially global in scope, has enriched the historical analysis of the globalization process, and particularly its successive transformations over the past two centuries.

This issue of Prospects is intended to contribute to this dynamic, with a view to illustrating its heuristic potential in historicizing educational phenomena and, through them, the knowledge of which they are composed, the actors who develop them, the institutions which encompass them, and the policies devoted to them. In this regard, we consider the field of education as a relevant platform for an analysis of transnational dynamics. Making it all the more intriguing, it has often been portrayed as being resistant to any form of intermixing or borrowing, just as schools are also frequently depicted as veritable closed-circuit conservatories of national identity. Professional historians heatedly debate this emphasis on a transnational perspective. In this issue, however, we use it in accordance with various authors included here, as a generic term pointing to various processes of exchanges, flows, and transfers that cannot be fully grasped within a unique national context. This issue challenges such "mainstream" perceptions with a diversity of case studies. It renews knowledge of the international production of education policies and practices to show that the educational field is indeed a pertinent location to observe this transnational dynamic, and it offers lessons and hypotheses which may be transposed to other fields of analysis.

But the study of phenomena that transcend borders is no more novel for historians of education than it is in other fields of historical research: interest in global phenomena has indeed been fed by historiographies that have already been richly investigated (Grosser 2011). Researchers in the field of education have clearly contributed to the growing awareness of transnational and global phenomena and processes; their long familiarity with the comparative methods used to develop knowledge of local, regional, national, and sometimes continental school systems is illustrated in many articles in Prospects, and by publications of the International Bureau of Education (IBE) and of UNESCO. In turn, historians of education have made a powerful contribution to this burgeoning field by outlining the historical context of these dynamics, with reference to a rich historiography, as shown in Caruso and Tenorth (2002); Fuchs (2006); MacCulloch and Lowe (2003); and Schriewer (1994), and in various special editions of Paedagogica Historica, including 
"Empires overseas" and "Empires at home" 2009; "Lost empires, regained nations" 2011; and "International in education: Issues, challenges, outcomes" 2014. The multiplicity of volumes covering the international flow of new education, education sciences, educational methods and theories, curricula, and the grammar of schooling over the past 20 years demonstrate the interest that historians of education take in phenomena that trespass national borders.

The present issue expands this movement and is intended to give greater visibility to the dissemination of actors, policies, knowledge, and aspirations and to identify more closely their influence on the co-production of education systems and the pedagogical knowledge on which they are based. The authors included in this issue have immersed themselves in archives to shed light on complex transfer mechanisms and to challenge the linear accounts of official narratives. All have endeavoured to base their analysis on empirical data reviewed in light of the theoretical motivations outlined by the recent "transnational turn" in historical research. They highlight the intricate interplay of micro- and macro-history, both for historical subjects and for the perspective they adopt to demonstrate the diversity of localizations of the global (hence the notion of "glocalization"); they also use a variety of scales of analysis to outline the mechanisms that facilitate the dissemination of knowledge through individual and collective actors and through material and representational channels. These authors understand educational phenomena as a dynamic space for dissemination and exchange; therefore, they illustrate the relevance of a resolutely historical approach to the study of these transnational processes, and the relevance of education and childhood as fertile grounds for applying a cross-border perspective. Their contributions cover a wide variety of historical contexts and specific educational issues to address key issues in historical debates on globalization that will be emphasized throughout this issue: periodization, the myth of progressivism, the multilaterality of circulatory phenomena, and gender relations.

\section{Worlds of education: Challenging traditional definitions of historical periods}

All the contributions focus on the specific periods covered by their respective subjects, and at the same time are sensitive to the more global dissemination mechanisms surrounding them and resonating with them (Saunier 2008a). They tend to indicate that the field of education is consonant with other fields that were particularly receptive to outside influences, such as social reform, addressed here by Joëlle Droux, or penal reform movements, examined by Eckhardt Fuchs. Both authors demonstrate that the internationalist wave between the wars was an extension of the internationalist dynamic of the late $19^{\text {th }}$ century, as illustrated by the many associations, leagues and networks through which the institutions and working methods would subsequently be formalized during the interwar years. Such conclusions support the idea, already advanced elsewhere (Conrad and Sachsenmaier 2012; Sluga 2013) that transnational exchanges, and nation states, both experienced unprecedented development in the second half of the $19^{\text {th }}$ century and up until World War I. During this period, when the most aggressive forms of nationalism emerged, networks of experts were formed and reinforced, thereby illustrating the strident discord between the historical rhythm of international relations and the timing of transnational dissemination, as recently emphasized by Iriye (2013). Conversely, the end of the conflict and the interwar years appeared to finally bring into unison the timing of diplomatic events and the intensification of transnational contacts and cooperation. It was particularly through the establishment of major inter-governmental organizations, which would attract an 
astonishing density of associative networks and centres of expertise, that this collaborative dynamic found its structure. Four authors demonstrate this phenomenon by focusing on specific organizations. Joëlle Droux looks at the Child Welfare Committee of the League of Nations, Leonora Dugonjić at the international schools created in Geneva and then New York, Rita Hofstetter at the International Bureau of Education, and Zoe Moody at a series of NGOs focused on defending the rights of the child. The creation of these permanent fora undoubtedly benefited the dissemination of cultural models and reforming measures, and the production of potentially universal standards, as these fora brought the spokespersons of civil society and the representatives of states into prolonged contact at an international level.

The contributors in this issue do not confine themselves to outlining the genesis of an unprecedented system of dissemination, concluding with the emergence of new organizations (Mackenzie 2010). They also go behind the scenes of these agencies. Joëlle Droux, Rita Hofstetter and Zoe Moody draw on recent publications (Gorman 2013; Kott and Droux 2013; Laqua 2011) to identify newly developed working methods, based on negotiations, tensions and competition between the organizations that formed the basis of international cooperation at the beginning of the 1920s. In particular, Joëlle Droux sheds light on the inventiveness of certain international networks, as illustrated by the Child Welfare Committee, through their position as representatives of international civil society and legitimate counterparts of sovereign states in the field of child welfare.

The developments described in these articles re-evaluate traditional histories of international relations, which produced the image of the 1920s as fertile in collaborative dynamics, in contrast with the 1930s, depicted as an era of rising national egoism. The archives of the institutions covered here (the International Union for Child Welfare, the International Bureau of Education, the International League for New Education, the League of Nations), reveal the rivalries that broke out between networks in the 1920s and were only resolved at the beginning of the 1930s, when international cooperation defined in a more consensual manner its methods of organization, its objectives, and the means of achieving them. This is shown by the International Conferences on Public Education, which the IBE initiated in 1932. During the 1930s, the IBE attained sufficient public support to finally bring together, in July 1939, the forty states affiliated with it (along with three observers from the League of Nations, the International Labour Office, and the International Institute of Intellectual Cooperation) to develop in a "fraternal spirit" a "charter of world aspirations for public education". From the viewpoint of educational issues, it would appear that international cooperation, and the channels of dissemination that fed into it, did not suffer the series of catastrophic ruptures associated with World War II between the 1930s and the beginning of the 1950s. Quite the contrary. Case studies of international institutions devoted to children between the wars show that the United Nations followed in their footsteps, benefitting from their work, networks, and expertise, thereby confirming the claims made by Renoliet (1999) for the International Organization of Intellectual Cooperation of the League of Nations. As she discusses the genesis, transformation, institutionalization, and finally the dissemination of the United Nations Declaration of the Rights of the Child of 1959, which was a direct descendant of the "Geneva" Declaration of the Rights of the Child of 1924, Zoe Moody (2014) demonstrates a similar relationship. Likewise, the articles by Marc Depaepe, Frank Simon, and Honoré Vinck; by Leonora Dugonjić; and by Valeska Huber corroborate Mazower's (2009) arguments (2009) regarding the continuities of knowledge and of know-how accumulated within international organizations and their surrounding networks between and beyond the two world wars. 
The international agencies and associations that organized international collaboration in the field of education and the actors who took centre stage in promoting it reveal trends that were independent of diplomatic developments. The contributions in this issue therefore revise our understanding of the traditional periods attributed to international collaboration. These authors do not ignore the major stages in the history of international relations; they situate the development of these international agencies in relation to those stages to demonstrate that, on their own, these developments do not give the whole picture of the complex evolution of globalization.

\section{Worlds of education: Challenging the narrative of progress}

Another shared characteristic of the contributions in this issue is that they raise questions about the assumed "progressive" nature of international circulations and collaborations. As several authors already emphasized in their critical assessment of the transnational approach and the results it has achieved, the transnational approach is often limited to the universal dissemination of high and mighty causes, and often confers a positive value synonymous with progress and modernity on disseminatory movements and the ideologies and representations that they convey (Haupt 2011; McDonald 2013; Saunier 2008b). Indeed, too little attention has been paid to the intense dissemination of conservative or reactionary ideals and principles such as xenophobic ideas and theories, the transnational dissemination of ultra-nationalist doctrines between the wars, or cultural imperialism during and beyond the colonial period.

Several articles in this issue refer to the international production of "crusades" with a high moral added value as a major motivation of internationalist commitment. Among them are establishing peace through education, building a new international community through international schools, guaranteeing the rights of the child, promoting the welfare of vulnerable infant populations, and improving the higher education of elites in the Middle East. At the same time, however, they also show that many of the zealous advocates of these humanistic causes were themselves sensitive to the uses to which they could be put and the possible hidden dangers of an overactive or committed militancy. In addition, several articles emphasize that circulation does not necessarily imply inclusion or emancipation in the field of education or in any other endeavour. Florian Waldow makes this point quite clearly in his analysis of the variability of the arguments underlying the legitimacy of international standards in the field of education during the $20^{\text {th }}$ century. While the scientific nature of such standards has often been cited to justify their use in various contexts, their use has also made it possible to calibrate education systems to the requirements of the economic world and its own standards of effectiveness. Abdeljalil Akkari and Thibaut Lauwerier further address the implications of this issue as seen in the current fad for benchmarking, not only by the OECD and the World Bank, but also by UNESCO and UNICEF, even though the latter give priority to a humanist vision of education. Eckhardt Fuchs discusses ways that the dissemination of models to control deviant youth follows a similar logic: standards in this field, formerly defined to a greater or lesser extent by international agencies, offer states model measures which may be justified by their apparent basis in new knowledge (particularly of a pedagogical and medical/psychiatric nature). Such dispositions may lead to increased social control of juvenile populations, hitherto taken into account only marginally in national social policies, under the pretext that they need "rehabilitation". On the subject of the pedagogical value of new education as channelled through the textbooks dedicated to students in the 
Congo by the pedagogue Hulstaert, their impact was, to say the least, ambiguous, as illustrated by Marc Depaepe, Frank Simon, and Honoré Vinck. Admittedly, these textbooks encouraged students to exercise independence as they acquired school knowledge, but that very independence was simultaneously constrained by a religious tradition that had nothing liberating about it. And the historians of new education have long demonstrated how this powerful universalist movement could also serve as a basis for nationalist indoctrination, particularly by Nazi and fascist totalitarian regimes. In the same way that internationalist causes can serve nationalist goals, the latter can also impose themselves on internationalist platforms, as shown in the articles by Joëlle Droux and Rita Hofstetter among others.

\section{Worlds of education: Challenging a linear vision of current trends}

Several contributions in this issue have a particularly acute sensitivity to the dialectical dimension of the mechanisms being examined, thereby highlighting the comparative and interconnected dimensions of educational trends. The approach consists of avoiding any stationary images so as to be able to understand the subject in its changing, dynamic and relational dimension (at the synchronic and diachronic levels) and to elucidate "action situations" (within the meaning given to them by Werner and Zimmermann 2003, pp. 24-26) in which the protagonists are studied while they work, travel, engage in dialogue, negotiate, and define positions. This approach also involves shedding light on the variations in their multiple directions and impacts, so as to avoid reasserting a linear and unilateral vision of a particular channel of dissemination, which would also suggest asymmetrical power relations (for example, by acting as the unilateral voice of missionaries, universal agents, or international organizations).

Accordingly, several authors show how the causes, knowledge, and models were reimplemented by those who communicated them as much as by their target groups. Transfers often occur through a whole network of localized borrowings and targeted appropriations, which may undermine their initial content. Just as progressive causes can result in strangulation, binding constraints can also be subverted to favour emancipatory dynamics. Nor can the impact of these means of dissemination necessarily be reduced to a form of reception that is more complex, or less so. This is not only because certain instances of dissemination failed to have an impact on the groups initially targeted, but also because, even when the export process "fails", forms of dissemination affect the channels which convey them and contribute to their transformation just as much as the dissemination of the models that they carry.

These processes of resémantisation (to use the term coined by French scholars, i.e, developing new meanings), have been tested in the field of education (Fontaine 2013) with reference to the trend toward cultural transfer, and Espagne (1999) has conducted fertile work in this area. These processes are particularly visible to those who do not take official speeches at face value. This is what makes it so valuable to travel, through archives, behind the scenes of these major international agencies through exchanges of correspondence, of personal agendas, of confidential notes. Or, in a particular institution, a researcher might note the subtlety of redefinitions, reinterpretations, and reappropriations to unearth subtle negotiations and compromises. Valeska Huber did this by listening attentively to phenomena of resistance, blockage and congestion; she challenges the idea of a direct transposition "of a piece of America into the Middle East" in her article on three American and Jewish universities in Beirut, Cairo, and Jerusalem, by showing how the university 
communities amalgamated several models to adapt to local circumstances and needs. Research into aspects of colonization (Ayachi 2003; Nguyen 2014) illustrates brilliantly the way that indigenous communities and local elites can use colonial vectors and institutions that transmit training and culture to promote emancipatory movements, as demonstrated by Depaepe, Simon and Vinck in this issue. If childhood and education are good places to frame and assign belongings and identities, and to consolidate citizenship and impose values, they are also conducive to the establishment of new networks, to the dissemination of new cultural references, to the production of utopias and to the reappropriation of voice, within the context of the various types of imperialism.

On the other hand, Leonora Dugonjić shows the difficulties that the advocates of the Geneva Ecolint encountered in "transferring" this "model institution" from Geneva when the United Nations was set up in New York. She also deconstructs the myth of the origins of this international school that the founders fabricated so that their new community of international officials would achieve social legitimacy: families, and particularly women, indeed gave it their support, but at the same time reappropriated the project and substantially reconfigured it. For a deeper analysis of this phenomenon, see Dugonjić (2014).

\section{Worlds of education: Challenging male-dominated internationalism}

The contributions in the present issue focus on the individual and collective actors who are the first links in this chain of the circulation of educational knowledge and policies. Many scholarly works have followed the careers of official ambassadors and cosmopolitan elites in their transnational negotiations and missions and have shed light on official organizations that presented themselves as new "world authorities" in the field of education. Far from denying their decisive role, the authors in this issue endeavour to place these leading figures in the context of their networks of formal and informal relations; they also identify the every bit as decisive, but more discrete, actions of associations, leagues, trade unions, militant factions, and alternative networks within and outside recognized official institutions. Moreover, these authors analyze the role of "invisible" actors, or those relegated to the sidelines. For example, as Depaepe and his colleagues consider Hulstaert, they include the role played by congregations of nuns; Waldow looks at the "missionaries" or foot soldiers of dissemination, such as Bobbit and Tyler; and Huber examines the role of Protestant networks in the model of American universities transposed to the Middle East. Joëlle Droux and Zoe Moody illustrate the marginalization of some interwar child-welfare movements and networks to place the history of child policies into a long-term context. They also show how recognition of their work by the League of Nations through the Charter of the Rights of the Child paradoxically led to its later being reappropriated by the United Nations.

The specific role played by women's associative networks in placing various issues related to equality onto the international agenda has been the subject of numerous fascinating studies (De Han, Allen, Purvis, and Daskalova 2013; Garner 2010; Rupp 1997), encompassing a broad range of subjects. Leading women actors and their networks have been explored by authors showing their nodal commitment at the periphery (as links between the local and the global contexts) and at the heart of international agencies, but without neglecting the tensions that split them into deeply opposed groups at the end of the $19^{\text {th }}$ century (Wiesner-Hanks 2011). The articles in this special issue are not concerned with these "major" figures of feminist internationalism; instead they offer insights, admittedly fewer than we would have liked, into the role of secondary figures who were 
crucially important in disseminating educational knowledge. Examples may be found in those hidden behind their veils as teaching sisters, and such "minor figures" as the innumerable secretaries of these associations, and the activists in women's associative networks, and later on the first "international civil servants" who were recruited or devoted themselves as volunteers to major international agencies responsible for disseminating information, models, data, and practices in the field of education. Leonora Dugonjić sheds light on the personality and international expertise of Thérèse Maurette: married to a former ILO civil servant, this seasoned internationalist was trained in Geneva and used her 20 years of experience in directing Ecolint in Geneva to assert herself as the first ambassador of its transfer to New York, so the United Nations could benefit from it as an experimental centre for international education. Analyzing how the International Bureau of Education in Geneva interacted with other international educational associations and state agencies responsible for education systems, Rita Hofstetter updates the decisive contribution that its secretary general, Marie Butts, made to ensuring recognition for the IBE and its goals, by writing hundreds of letters, in many languages, to mobilize her networks of relations and well-known educational figures.

Figures such as Maurette and Butts deserve a substantive study to reveal the characteristics of their development, their social relations, their positioning within several reforming networks, and the impact of their activism, both in terms of interagency contacts and the implementation of the standards they produced. The information presented here on these shadowy figures of women's internationalism is bound to underestimate their role, as their ubiquitous presence in the educational field suggests a broader and more lasting influence. It remains to be seen how women's internationalism exercised influence and how, in a world broadly dominated by powerful men, they were able to make their voices heard, and on what subjects and through what characteristics in their approach. These are all areas of research that remain to be explored and where the archives of international organizations and private associations, and later on epistemic communities and international networks (of women graduates, students, and members of teachers' organizations), hold the promise of a plethora of first-hand resources.

There is still much to do to deepen our understanding of the phenomena of globalization and internationalization that affect the educational field and the configuration of circulations in this area through time and space. Scholars in this field have a bright future, especially if they aim to reduce the blind spots through research into non-Western areas, or into the effects of circulations on school populations, or into direct contact with the education system (children, youth, teachers, families), or the impact of these nomadic mechanisms on school-related knowledge, and its production, translation, importation, teaching, and reception. Many research topics, issues, and challenges remain in the effort to renew the history and narratives of the worlds of education in a globalized context.

\section{References}

Ayachi, M. (2003). Ecoles et société en Tunisie (1930-1958) [Schools and society in Tunisia (1930-1958)]. Tunis: CERES.

Caruso, M., \& Tenorth, H. E. (Eds.) (2002). Internationalisierung/Internationalisation: Semantik und Bildungssystem in vergleichender Perspektive [Internationalization: Semantics and educational systems in comparative perspective]. Frankfurt am Main: Peter Lang.

Clavin, P. (2005). Defining transnationalism. Contemporary European History, 4(14), 421-439. 
Clavin, P. (2011). Conceptualising internationalism between the world wars. In D. Laqua (Ed.), Internationalism reconfigured: Transnational ideas and movements between the world wars (pp. 1-14). London: I.B. Tauris.

Conrad, S., \& Sachsenmaier, D. (Eds.) (2012). Competing visions of world order: Global moments and movements, 1880s-1930s. Basingstoke: Palgrave-Macmillan.

De Han, F., Allen, M., Purvis, J., \& Daskalova, K. (2013). Women's activism: Global perspectives from 1890 s to the present. London, New York: Routledge.

Dugonjić, L. (2014). Les IB schools, une internationale élitiste: Emergence d'un espace mondial d'enseignement secondaire au XXe siècle [IB schools: An international elite: Emergence of a global space for secondary education in the $20^{\text {th }}$ century]. Doctoral thesis, Ecole des hautes études en sciences sociales and University of Geneva (FPSE).

Espagne, M. (1999). Les transferts culturels franco-allemands [Franco-German cultural transfers]. Paris: PUF.

Fontaine, A. (2013). Transferts culturels et déclinaisons de la pédagogie européenne: Le cas franco-romand au travers de l'itinéraire d'Alexandre Daguet (1816-1894) [Cultural transfers and specificities of European pedagogy: The Franco-Romand case through the trajectory of Alexandre Daguet (1816-1894)]. Doctoral thesis, ENS-Paris and Fribourg.

Fuchs, E. (Ed.) (2006). Bildung International. Historische Perspektiven und aktuelle Entwicklungen [International education: Historical perspectives and actual development]. Würzburg: Ergon.

Garner, K. (2010). Shaping a global women's agenda: Women's NGOs and global governance, $1925-85$. Manchester and New York: Manchester University Press.

Gorman, D. (2013). The emergence of international society in the 1920s. Cambridge: Cambridge University Press.

Grosser, P. (2011). L'histoire mondiale/globale, une jeunesse exubérante, mais difficile [Global history: An exuberant but difficult beginning]. Vingtième Siècle. Revue d'histoire, 110(2), 3-18.

Haupt, H. G. (2011). Une nouvelle sensibilité: La perspective "transnationale": Une note critique [A new sensitivity: The 'transnational' perspective: A critical assessment]. Cahiers Jaurès, 2(200), 173-180.

Iriye, A. (2013). Global and transnational history: Its past, present, and future. Basingstoke: Palgrave Macmillan.

Iriye, A., \& Saunier, P. Y. (Eds.) (2009). Palgrave dictionary of transnational history. Basingstoke: Palgrave Macmillan.

Kott, S., \& Droux, J. (Eds.) (2013). Globalizing social rights: The International Labour Organization and beyond. Basingstoke: Palgrave Macmillan.

Laqua, D. (2011). Transnational intellectual cooperation, the League of Nations, and the problem of order. Journal of Global History, 6, 223-247.

Macdonald, S. (2013). Transnational history: A review of past and present scholarship. London: University College London. http://www.ucl.ac.uk/cth/objectives/simon_macdonald_tns_review.

Mackenzie, D. (2010). A world beyond borders: An introduction to the history of international organizations. Toronto: University of Toronto Press.

Mazower, M. (2009). No enchanted palace: The end of empire and the ideological origins of the United Nations. Princeton: Princeton University Press.

McCulloch, G. \& Lowe, R. (Eds.) (2003). Centre and periphery: Networks, space and geography in the history of education. History of Education (special issue) 32(5).

Minard, P. (2013). Globale, connectée ou transnationale: Les échelles de l'histoire [Global, connected or transnational: The levels of history]. Esprit, 12, 20-32.

Moody, Z. (2014). L'enfant sujet de droits: Processus transnational de genèse, d'institutionnalisation et de diffusion des droits de l'enfant (1924-1989) [Rights for children: The transnational process of the genesis, institutionalization and dissemination of the rights of the child (1924-1989)]. Doctoral thesis, University of Geneva (FPSE).

Nguyen, T.-P. (2014). The rivalry of the French and American educational missions during the Vietnam War. Paedagogica Historica, 50(1-2), 27-41.

Renoliet, J.-J. (1999). L'UNESCO oubliée. La Société des Nations et la coopération intellectuelle (1919-1946) [The forgotten UNESCO: The League of Nations and intellectual cooperation (1919-1946)]. Paris: Publications de la Sorbonne.

Rupp, L. (1997). Worlds of women: The making of an international women's movement. Princeton: Princeton University Press.

Saunier, P. Y. (2008a). Les régimes circulatoires du domaine social 1800-1940: Projets et ingénierie de la convergence et de la différence [Dissemination networks in the social field 1800-1940: Projects and engineering for convergence and difference]. Genèses, 2(71), 4-25. 
Saunier, P. Y. (2008b). Learning by doing: Notes about the making of the Palgrave Dictionary of Transnational History. Journal of Modern European History, 6, 159-179.

Schriewer, J. (1994). Welt-System und Interrelations-Gefüge. Die Internationalisierung der Pädagogik als Problem Vergleichender Erziehungswissenschaft [The world system and the search for interrelationships: Seeing the internationalizing of education as a problem of comparative educational sciences]. Berlin: Humboldt-Universität.

Sluga, G. (2013). Internationalism in the age of nationalism. Philadelphia: University of Pennsylvania Press. Tyrrel, I. (2009). Reflections on the transnational turn in United States history: Theory and practice. Journal of Global History, 4, 453-474.

Werner, M., \& Zimmermann, B. (2003). Penser l'histoire croisée: Entre empirie et réflexivité [Thinking “entangled" history: Between empiricism and reflexivity]. Annales. Histoire, Sciences Sociales, 58(1), $7-36$.

Wiesner-Hanks, M. E. (2011). Crossing borders in transnational gender history. Journal of Global History, $6(3), 357-379$.

Joëlle Droux (Switzerland) is a senior lecturer at the University of Geneva, Faculty of Psychology and Education, and co-leader of ERHISE (Social History of Education Research Group). She studies the history of international child welfare movements and the contemporary evolution of social and humanitarian networks from a transnational perspective. She also develops research projects on the long-term evolution of Swiss policies for child and youth welfare.

Rita Hofstetter (Switzerland) is full professor and chair of the Department of Educational Sciences at the University of Geneva. She is also director of the Jean-Jacques Rousseau Institute's archives, and coordinator of ERHISE (Social History of Education Research Group). Her research focuses on the history of the educational sciences (including that of the Rousseau Institute), the construction of the teaching state and the teaching profession, and international networks in education (including the history of the International Bureau of Education). 